\title{
The Impacts of Complaint Satisfaction on Corporate Reputation: A Study on Banking Sector
}

\author{
Adnan Duygun, S. Ahmet Menteş, and Ahmet Kubaş
}

\begin{abstract}
This research aims to develop and test a model to reveal the influence of complaint satisfaction on corporate reputation. Data were gathered through survey from bank customers who complained about banking service in any issue at least once and whose complaints were evaluated by the bank during the last year. The results show that the customers have not been satisfied concerning their complaints. The results exhibit that the complaint satisfaction has positive effects on corporate reputation.
\end{abstract}

Index Terms-Complaint satisfaction, corporate reputation, expected justice, perceived justice.

\section{INTRODUCTION}

Companies try hard to survive in the competitive environment of our era. The main focus of these efforts is on the customers that are also the most important shareholders for which the companies work. In particular, the satisfaction of customers and the complaint solution are among the most important aspects that they especially need to focus on. Additionally, having a good corporate reputation helps companies to be different from their competitors and be one step in front of them. Therefore, the corporate reputation is another important matter of concern of the companies.

From this point on, it is useful to examine the relationship between corporate reputation and complaint solution and the corresponding practices for customer satisfaction. This situation is much more important in service industry and, consequently, this research has been conducted on banking services.

\section{LITERATURE REVIEW}

Service mistakes and failures are frequent occurrences. In order to excel, service organizations need to analyze these occurrences systematically and find effective solutions to the service failures and customer complaints. One of the main approaches related to the handling of customer complaint focuses on the justice of the process which would bring a solution to the complaint. Justice, the basic principle of all exchanges, is also the basic principle in resolving complaints. The basis of justice concept is derived from social psychology. The principles of justice have been analyzed in the framework of the fairness of employee salaries, employee

Manuscript received August 1, 2013; revised October 10, 2013.

Adnan Duygun is with Istanbul University, Istanbul 34413 Turkey (e-mail: adnanduygun@yahoo.com).

S. Ahmet Menteş and Ahmet Kubaş are with Namık Kemal University, Tekirdag 59000 Turkey (e-mail: ahmetmentes@yahoo.com, ahmetkubas@yahoo.com). relations, legal disputes and a relatively new subject customer-seller justice in commerce. The research done on corporate, customer-seller and marital relations has proved that, while explaining the reactions to the solutions, the concept of justice is really important [1], [2].

During the process of complaint resolution, the justice to reactions of corporations is perceived and evaluated in three dimensions. These dimensions are distributive justice, procedural justice and interactional justice [1]-[4]. Distributive justice is the perception of the benefits (remedies) being enough for the customer on the complaint solution process in terms of equality, sufficiency to meet the necessity, and justice. Procedural justice is related to the gathering of the data, decision maker's usage of the data, and opportunity for the customer to prove his or her point on the conclusion, accessibility, timing, and flexibility. On the other hand, interactional justice is composed of the rudeness and inappropriateness of the behaviour of the personnel and the combination of the negative and positive behaviours like explaining, honesty, kindness, empathy, effort, or listening [5], [6].

Corporate reputation can be defined as the customer perception of how well a company takes care of customers and is concerned about their welfare. Customers' perceptions of a firm can occur directly through exposure to its products and services. However, many firms develop reputations, good and bad, without such a direct contact. Important insights on many products and services can occur through comments from friends, family members, and colleagues. Firm reputation has received attention from marketing researchers. The research has proven that the reputation affects customers' product choice, overall attitudes about products and services, trust, and purchase intentions. Despite these results, firm reputation has not been examined in detail within a customer complaint/failure context [7].

There is much research conducted on corporate reputation. One of the best known research is Fortune's "World's Most Admired Companies Survey". The criteria used in this research are product and service quality, management quality, long-term investment value, attracting human resources, the usage of resources, globalization, financial robustness, creativity and innovation, and social responsibility [8].

Another research is reputation quotient (RQ). The criteria used in this research are emotional attraction, products and services, vision and leadership, workplace environment, social responsibility and financial performance [9]. The criteria used in Rep Trak model, which is a more developed version of reputation quotient, are product and services, innovation, workplace environment, governance, citizenship (social responsibility), leadership and performance [10]. Rep 
Trak Model is used in our research.

\section{Methodology AND FindingS}

\section{A. The Purpose, Scope and Limitations of the Research}

The purpose of our research is to develop and test a model to reveal the influence of complaint satisfaction on corporate reputation (firm reputation).

Anyone having a bank account in at least a bank for two years and complaining about at least a subject to the bank, and whose complaint has been evaluated by the bank in the last year, is in the scope of this research. Taking into consideration the high number of customers who have complained to the bank and the difficulty in finding all of them as well as the limitations of time and cost, it has been decided to conduct a pilot study on bank customers who meet the above mentioned criteria. The research has been carried out involving customers residing in Istanbul.

\section{B. The Model, Variables and Hypothesis of the Research}

As seen in Fig. 1, the justice evaluation of the customers' complaint solution in complaint management (process) is evaluated on the basis of their expectations pre-complaint and their perceptions post-complaint. Customers' satisfaction about complaint management (process) is based on the difference between their expectations and perceptions. This is known in the literature as the paradigm of disapproval. When the paradigm of disapproval is seen from the perspective of complaint management (process), if the customers' expectations of complaint management (process) equal the perceptions post-complaint, it means that expectation and perception approves one another. If expectation is higher than perception, it is negative disapproval and if perception is higher than expectation, it is positive disapproval [11], [12]. As it can be understood from the model, while handling with the complaints, at least a performance that aims to equal expectations and perceptions should be put into practice.

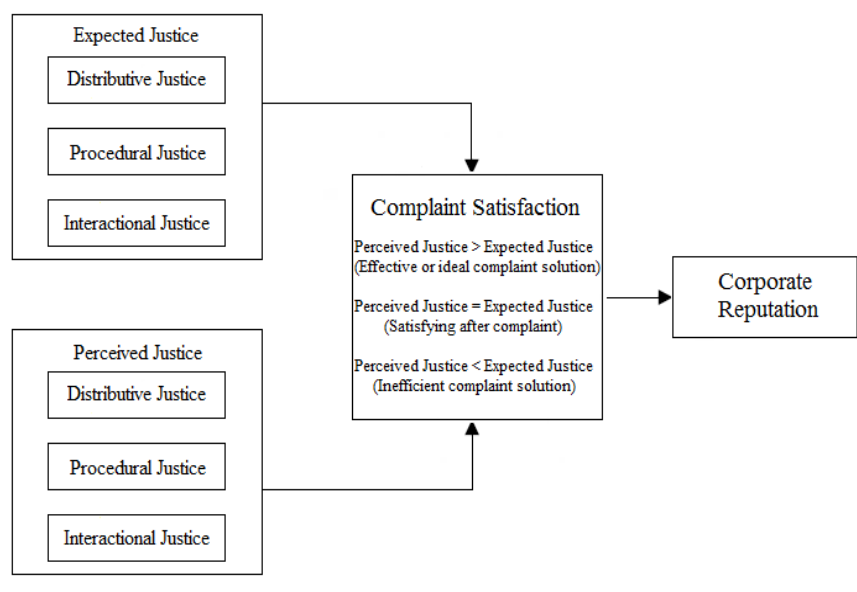

Fig. 1. Model of the research.

It is also thought in the model that customers' satisfaction after complaint solution process affects customers' perception of corporate reputation. Variables of the research are shown in Table I. Additionally, the resources that were used while defining and adapting the variables are shown in
Table I. The variables were asked in questionnaire format by using a five-point Likert scale.

TABLE I: VARIABLES OF THE RESEARCH

\begin{tabular}{|l|l|l|}
\hline Variables & $\begin{array}{l}\text { Number of } \\
\text { Variables }\end{array}$ & Resource \\
\hline $\begin{array}{l}\text { Socio-Demographic } \\
\text { Variables }\end{array}$ & 4 & {$[4][13][14]$} \\
\hline $\begin{array}{l}\text { Distributive Justice } \\
\text { Variables }\end{array}$ & 4 & {$[4][13][14]$} \\
\hline $\begin{array}{l}\text { Procedural Justice } \\
\text { Variables }\end{array}$ & 3 & {$[4][13][14]$} \\
\hline $\begin{array}{l}\text { Interactional Justice } \\
\text { Variables }\end{array}$ & 4 & {$[15]$} \\
\hline $\begin{array}{l}\text { Corporate Reputation } \\
\text { Variables }\end{array}$ & $\begin{array}{l}7 \text { Factors, 23 } \\
\text { Variables }\end{array}$ & \\
\hline
\end{tabular}

As mentioned earlier, the basic factors that compose Rep Trak model are goods and service quality, innovation, workplace environment, governance, social responsibility, leadership and performance. These factors consist of a total of 23 variables. These variables were readjusted to the banking services on which the study was to be conducted. Then, necessary changes were done and the obtained data were included in the research.

Hypotheses of the research can be listed as it follows:

- $\mathrm{H}_{1}$ : There is a statistically significant difference of $\alpha=$ 0.05 significance level in the customers' justice expectation of complaint solution process and their perception of justice post-complaint.

- $\mathrm{H}_{2}$ : Complaint satisfaction has a statistically positive impact on corporate reputation at a significance level of $\alpha=0.05$.

\section{Sampling Plan}

The number of persons as bank customers involved in the present study is of 75.846. Because of the above mentioned reasons, it has not been possible to perform the questionnaire on all of them. For this reason, a sampling plan has been conceived. As it is not possible for most of the times to know the standard deviation and variance in the population, it has to be estimated. Such estimation is easier achieved via rates. Even in cases in which there is no information about these rates, the value $(0.5 \times 0.5=0.25)$, where $P(1-P)$ is the highest, can be accepted. Because of all these reasons, the most common sampling formula in practice is the following: $n=P(1-P) /(e / z)^{2}[16]$. According to this formula, the sample size should be 384 persons of 75.846 persons as the value of $z$ is 1.96 for the maximum variance $(0.5 \times 0.5=0.25)$ and $95 \%$ of confidence interval.

Concerning the sampling method, the simple random sampling was used. Some 500 persons were included in the research in case there may be questionnaires which are not correctly filled in or not all the people are accessible. Of all the questionnaires, some 425 were observed to be useful.

\section{RESUlTS AND SUGGESTIONS}

In the research, the complaint satisfaction's impacts on corporate reputation are examined. The main focus is on the measuring of the difference between customers' expectations of justice and their perceptions of justice after complaint solution process and this difference was regarded as 
complaint satisfaction. While measuring corporate reputation, Rep Trak model has been used and the variables of this model have been adapted to the banking services. The research has been conducted on customers possessing bank accounts and having complained to the bank.

By focusing on the model in Fig. 1, two hypotheses have been put forward and tested. As seen in Table II, the results of these hypotheses can be summarized as the following:

TABLE II: HYPOTHESES TEST RESULTS

\begin{tabular}{|c|c|}
\hline $\begin{array}{l}\mathrm{H}_{1} \text { : There is a statistically significant difference of } \alpha= \\
0,05 \text { significance level in the customers' justice } \\
\text { expectations of complaint solution process and their } \\
\text { perception of justice post-complaint. }\end{array}$ & ACCEPTED \\
\hline $\begin{array}{l}\mathrm{H}_{2} \text { : Complaint satisfaction has a statistically positive } \\
\text { impact on corporate reputation at a significance level } \\
\text { of } \alpha=0,05 \text {. }\end{array}$ & ACCEPTED \\
\hline
\end{tabular}

\section{IMPLICATIONS}

The present research offers important results to managers. Primarily, bank employees should well understand the difference between the expected and perceived justice and while handling a complaint and solving it, they should always pay the required attention to the customer. If needed, they should get the required education for doing that.

Secondly, when it is considered that the complaint solution has a positive effect on corporate reputation, it is clear that the handling of complaints also has an effect on the bank's corporate reputation. Therefore, the solutions for the complaint solution process become even more important to satisfy the customers.

\section{LIMITATIONS AND FUTURE RESEARCH}

There are some limitations of this research. For instance, the study has been conducted only in relation to the banking services and in a specific area which is that of Istanbul, Turkey. Therefore, the results of the research cannot be generalized to other service areas and other geographical regions. For this reason, the research should be performed separately for other services and other geographical regions.

\section{CONCLUSION}

In the researches done before, the relationship between perceived justice and complaint satisfaction is examined separately. The complaint satisfaction relies on the difference between the expectations pre-complaint or the perceived justice post-complaint. When the difference between perceived justice and expected justice is examined, it can be understood that the customers are not satisfied with the complaint solution. Additionally, the number of studies showing the relationship between complaint satisfaction and corporate reputation is limited. Our research shows that the complaint satisfaction has a positive impact on corporate reputation.

\section{REFERENCES}

[1] G. Barış, Complaint Management for Excellent Customer Satisfaction, MediaCat Books, 2nd ed. Istanbul, 2006, pp. 118.
[2] S. S. Tax, S. W. Brown, and M. Chandrashekaran, "Customer evaluation of service complaint experiences: Implications for relationship marketing," Journal of Marketing, vol. 62, pp. 60-76, April 1998.

[3] J. G. Blodgett and R. D. Anderson, "A Bayesian network model of the consumer complaint process," Journal of Service Research, vol. 2, no. 4, pp. 321-338, 2000.

[4] J. G. Blodgett, D. J. Hill, and S. S. Tax, "The effects of distributive, procedural, and interactional justice on post complaint behavior," Journal of Retailing, vol. 73, no. 2, pp. 185-210, Summer 1997.

[5] C. Goodwin and I. Ross, "Consumer evaluations of responses to complaints: What's fair and why?" Journal of Services Marketing, vol. 4, no. 3, pp. 53-61, 1990.

[6] İ. Gökdeniz, İ. Bozacı, and E. Karakaya, "Applied Research on the Factors that Affecting on After Complaint Management Process," Journal of Selçuk University Social Sciences, no. 26, pp. 173-185, 2011.

[7] D. Nikbin, H. Armesh, A, Heydari, and M. Jalalkamali, "The effects of perceived justice in service recovery on firm reputation and repurchase intention in airline industry," African Journal of Business Management, vol. 5, no. 23, pp. 9814-9822, October 2011.

[8] M. Morley, How to Manage Your Global Reputation: A Guide to the Dynamics of International Public Relations, New York University Press, New York, 2002.

[9] R. Chun, "Corporate reputation: Meaning and measurement," International Journal of Management Review, vol. 7, no. 2, pp. 91-109, 2005.

[10] A. Trotta and G. Cavallaro, "Measuring corporate reputation: A framework for Italian banks," International Journal of Economics and Finance Studies, vol. 4, no. 2, pp. 21-30, 2012.

[11] J. J. J. Cronin and S. A. Taylor, "Measuring service quality: A reexamination and extension," Journal of Marketing, vol. 56, pp. 55-68, July 1992.

[12] M. Tarım, "The Measurement of Service Quality on Health Sector: SERVQUAL Model and A Hospital Application," Journal of Istanbul University Faculty of Economics, vol. 52, no. 2, pp. 15-36, 2002.

[13] M. Davidow, "Have you heard the word? The effect of word of mouth on perceived justice, satisfaction and repurchase intentions following complaint handling," Journal of Consumer Satisfaction, Dissatisfaction and Complaining Behavior, vol. 16, no. 3, pp. 67-80, 2003.

[14] J. Wirtz and A. S. Mattila, "Consumer responses to compensation, speed of recovery and apology after a service failure," International Journal of Service Industry Management, vol. 15, no. 2, pp. 150-166., 2004.

[15] Reputation Institute. (July 2013). [Online]. Available: http://www.reputationinstitute.com/about-reputation-institute/the-reptr ak-framework

[16] K. Kurtuluş, Reseach Methodolgy for Business (Research Methods), Istanbul, Faculty of Business Publication Number: 210, Business Economics Institute Publication Number: 106, 1989, pp. 113.

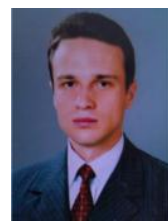

Adnan Duygun works as a freelance management consultant and lecturer at various universities. Mr. Duygun holds master degrees in marketing, management and international trade. Mr. Duygun is also in process of completing his Ph.D. thesis at Istanbul University.

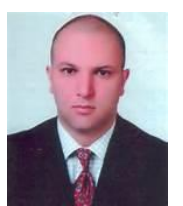

S. Ahmet Mentes is an associate professor at Namık Kemal University. Dr. Menteş has a master of science in finance (MSF) from Bentley College Graduate School of Business and holds a Ph.D. in management from Istanbul University.

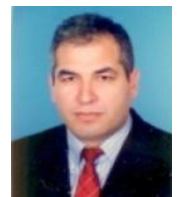

Ahmet Kubaş is a professor at Namık Kemal University. Dr. Kubaş has a master of science in agricultural economics from Trakya University and holds a Ph.D. in agricultural economics from Trakya University. 